\title{
PENGARUH MOTIVASI, PENGETAHUAN AKUNTANSI, DAN RELIGIUSITAS TERHADAP KUALITAS LULUSAN PROGRAM STUDI AKUNTANSI SYARIAH
}

\author{
Azza Nikmatuttisaroh \\ Program Studi Akuntansi Syariah \\ Sekolah Tinggi Ekonomi Islam SEBI \\ Email: zha_rain@yahoo.com
}

\begin{abstract}
Along with the development of economy and business, the competitiveness of it is increasing. Increasing competitiveness requires educational institutions to continuously improve the quality of graduates. This study aims to determine the effect of motivation, knowledge of accounting, and religiosity on the quality of graduatesin STEI SEBI Islamic Accounting courses. The sources of data in this study is the primary data obtained directly from responses to questionnaires of Islamic Accounting graduates tudy program. Data collection techniques is performed by the survey. Data obtained using a questionnaire administration to graduates of Islamic Accounting courses. The sample selection is done by using random sampling method. The data is analysed by the test of descriptive statistics, test of validity and reliability, the assumptions of classical test (test of normality, multicollinearity, and heteroskedastisity), as well as multiple linear hypothesis test. The results of the research shows that the partial motivation test is not significantly by the quality of graduates, while knowledge of accounting is significantly influence on religiosity at 95\% confidence level. Simultaneously, motivation, knowledge of accounting, and religiosity significantly influence the quality of graduates. R Square value in this study is 0.373 , which means that $37.3 \%$ changes in the level of quality of graduates can be explained by the variables of motivation, knowledge of accounting, and religiosity, while the rest is influenced by other variables that are not observed in this study. The results of this study are expected to contribute towards improving the quality of graduates of Islamic Accounting courses as a consideration in determining the necessary policies.
\end{abstract}

Keywords: Measurement, Islamic banking, maqoshid index.

\section{PENDAHULUAN}

Sistem ekonomi dan bisnis berlandaskan sistem ekonomi islam mengalami perkembangan yang pesat di Indonesia. Perkembangan ini terutama terjadi di sektor keuangan.Salah satu sektor keuangan yang mengalami perkembangan adalah perbankan syariah. Berdasarkan statistik perbankan syariah, jaringan kantor perbankan syariahhingga September 2011, 11 bank umum syariah memiliki 1.349 kantor, 23 unit usaha syariah pada bank umum konvensional memiliki 300 kantor, dan 154 bank pembiayaan rakyat syariah memiliki 362 kantor. Jadi, total keseluruhan jaringan kantor perbankan syariah sebanyak 2.011 kantor. 
Seiring dengan peningkatan perkembangan perbankan syariah di Indonesia, maka industri perbankan syariah pun membutuhkan Sumber Daya Manusia (SDM) yang menentukan laju pertumbuhan industri syariah ke depan. Outlook perbankan syariah 2012 menggambarkan bahwa pertumbuhan bisnis perbankan syariah secara moderat diperkirakan akan naik sebesar 36\% sehingga secara tidak langsung akan mempengaruhi kebutuhan SDM industri perbankan syariah tersebut. Direktur Utama BNI Syariah, Rizqullah menyampaikan bahwa banyaknya kebutuhan akan tenaga kerja tersebut pada tahun 2012 ini dapat dihitung dengan asumsi yang merujuk pada rasio aset dibanding jumlah pegawai. (www.ib.eramuslim.com)

Hingga September 2011, total pegawai perbankan syariah berjumlah 26.397 orang. Perbankan syariah masih membutuhkan tenaga kerja untuk 2012 hampir mencapai 10.000 orang. Jumlah tenaga kerja tersebut juga secara tidak langsung termasuk didalamnya terdapat kebutuhan untuk tenaga akuntansi syariah.

Perkembangan perbankan syariah tersebut harus dapat diimbangi dengan perkembangan berbagai fasilitas pendukung agar praktik ekonomi islam tetap dapat bertahan dantidak mengalami berbagai kesulitan karena lemahnya perangkat pendukungnya. Akuntansi merupakan suatu perangkat pendukung yang sangat menentukan suksesnya praktik ekonomi islamsecara nyata.

Oleh karena itu,dibutuhkanSDM yang dapat memahami akuntansi syariah secara utuh hingga nantinya perbankan maupun lembaga syariah lainnya tidak mengalamikesulitan dalam mencari SDM Syariah yang handal dan berkualitas. Lembaga pendidikan, khususnya lembaga pendidikan yang membuka Program Studi Akuntansi Syariah berperan penting untuk mengatasi kesulitan akan kebutuhan tersebut.

Sekolah Tinggi Ekonomi Islam SEBI (STEI SEBI) sebagai salah satu sekolah tinggi yang membuka Program Studi Akuntansi Syariah merupakan salah satu pendidikan profesional yang bertempat di Depok. STEI SEBI berupaya untuk berkontribusi dalam pencapaian dan peningkatan SDM Akuntansi Syariah melalui Program Studi Akuntansi Syariah yang telah dibukanya. Program Studi Akuntansi Syariah merupakan suatu program terintegrasi yang bertujuan untuk memfasilitasi terbentuknya sarjana-sarjana berakhlakul karimah, memiliki wawasan dan keterampilan dibidang akuntansi beserta pengintegrasiannya dengan nilai-nilai Islam, dan jiwa kewirausahaan yang mumpuni untuk bergelut di lapangan muamalah baik komersial maupun nirlaba, sehingga nantinya lulusan dari Program Studi Akuntansi Syariah ini merupakan lulusan yang berkompeten dan mampu bersaing di dunia kerja. (www.sebi.ac.id)

Dewasa ini, Program Studi Akuntansi Syariah STEI SEBI mengalami perkembangan yang cukup mengesankan. Perkembangan tersebut terlihat oleh tingginya jumlah mahasiswa aktif pada Program Studi Akuntansi Syariah pada semester akhir setiap tahunnya.

Jumlah mahasiswa aktif Program Studi Akuntansi Syariah, kecuali pada angkatan 2005-2007 yang merupakan jumlah dari mahasiswa Akuntansi 
Syariah dan Akuntansi Manajemen Zakat dikarenakan pada tahun tersebut telah dibuka konsentrasi Akuntansi Manajemen Zakat. Jumlah mahasiswa aktif Program Studi Akuntansi Syariah pada angkatan 2001 hanya berjumlah 17 orang, tetapi saat ini pada angkatan 2011 jumlah mahasiswa aktif Program Studi Akuntansi Syariah telah mencapai 50 orang. Meskipun telah ada peningkatan dalam jumlah mahasiswa aktif pada Program Studi Akuntansi Syariah, tetapi selama empat tahun terakhir yaitu pada angkatan 2004-2007 setiap tahunnya selalu ada mahasiswa yang lulus tidak tepat waktu ( lebih dari 4 tahun/ 8 semester).

Grafik 1. Data Lulusan Program Studi Akuntansi Syariah

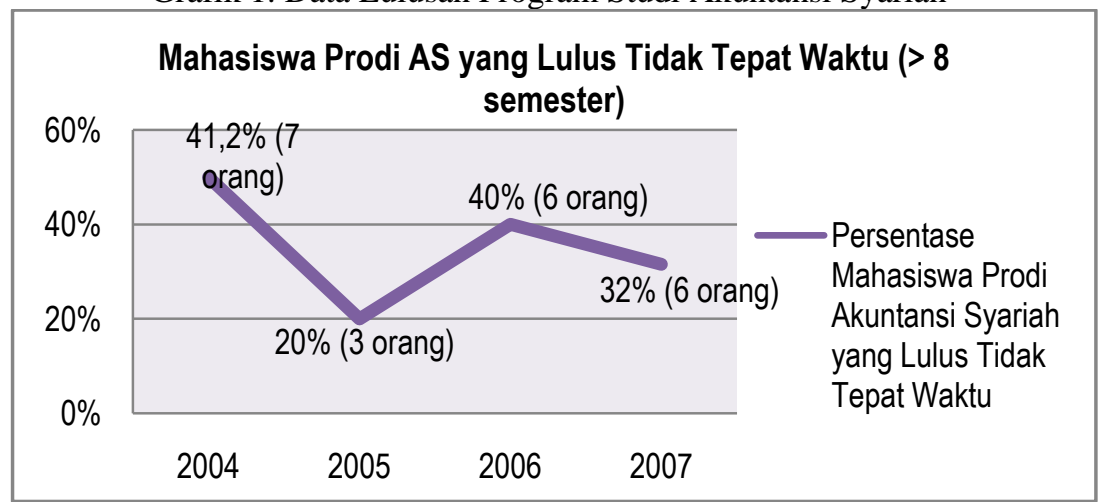

Sumber: data diolah, 2012

Lulus dengan mencapai gelar S1 saja tidak cukup bagi lulusan prodi Akuntansi Syariah. Agar dapat bersaing dalam dunia kerja SDM pun dituntut untuk memiliki kemampuan dan pengetahuan sesuai bidangnya masingmasing. Begitupun dalam Program Studi Akuntansi Syariah, maka mahasiswa lulusan Prodi Akuntansi Syariah pun tentunya harus memiliki kualitas yang mumpuni. Terdapat beberapa faktor yang mempengaruhi kualitas lulusan. Beberapa faktor tersebut sebagaimana dijelaskan dalam penelitian-penelitian terdahulu.

Penelitian mengenai Motives, Expectations and Preparedness dalam kaitannya dengan keberhasilan akademik dilakukan oleh (Byrne \& Flood, 2005) dan (Arquero, Gonzales, etc, 2009). Secara umum penelitian tersebut menjelaskan bahwa Motives, Expectations and Preparedness yang dapat diartikan sebagai Motif, Harapan, dan Kesiapan untuk berhasil atau berprestasi memiliki hubungan yang positif terhadap Keberhasilan Akademik pada Mahasiswa Akuntansi di salah satu universitas di Spanyol dan Irlandia.

Penelitian lain tentang keberhasilan yang dilihat dari kinerja (performance) pegawai dengan variabel religiusitas dengan lima dimensinya yaitu Pengaruh Religiusitas terhadap Prestasi Kerja. Penelitian tersebut menyatakan bahwa religiusitas memiliki pengaruh yang signifikan terhadap prestasi kerja Pegawai Negeri (PNS) alumni dan bukan alumni pesantren yang berkarya di Kantor Departemen Agama Kota Malang dimana dimensi 
yang secara signifikan mempengaruhi, yaitu Dimensi Keyakinan, Pengamalan, dan Pengalaman. (Fauzan \& Setiawati, 2010).

Dalam penelitian yang dilakukan oleh Siregar, diketahui bahwa pengetahuan akuntansi memiliki pengaruh yang signifikan terhadap kinerja manajerial pada tingkat kepercayaan $95 \%$ (2009). Penelitian lain terkait variabel pengetahuan akuntansi pun dilakukan oleh (Subowo \& Marfuah, 2006) yang hasilnya adalah variabel pengetahuan akuntansi mempunyai hubungan positif signifikan terhadap kinerja pegawai penyusun laporan keuangan di lingkungan Badan Wakaf UII.

Berdasarkan penjelasan-penjelasan dari penelitian terdahulu dengan konteks bahwa kinerja ataupun prestasi dalam penelitian ini merupakan keberhasilan yang dicapai para lulusan prodi akuntansi syariah, dimana keberhasilan studi ini nantinya akan menentukan kualitas lulusan dalam perguruan tinggi. Setiap perguruan tinggi pasti berharap dapat menghasilkan lulusan-lulusan yang berkualitas, maka menjadi menarik ketika melakukan penelitian yang mengukur faktor-faktor yang dapat mempengaruhi kualitas lulusan. Oleh karena itu maka rumusan masalah yang diajukan dalam penelitian ini adalah :

a. Bagaimanakah tingkat motivasi, pengetahuan akuntansi, dan religiusitas lulusan Program Studi Akuntansi Syariah?

b. Apakah variabel motivasi, pengetahuan akuntansi, dan religiusitas berpengaruh signifikan terhadap kualitas lulusan Program Studi Akuntansi Syariah baik secara parsial maupun simultan?

\section{LANDASAN TEORI}

\subsection{PENGERTIAN KUALITAS LULUSAN}

IEEE dan ISO 9000 mendefinisikan kualitas sebagai "kesesuaian dengan tujuan," yang juga mirip dengan definisi kualitas yang diterima luas yang dibuat oleh Philip Crosby (1979) yaitu "kesesuaian dengan yang disyaratkan". (Thomset, $2003: 112$ )

Dalam konteks dunia bisnis, kualitas didefinisikan sebagai berikut :

"Quality : A basic business strategy that provides goods and services that completely satisfy both internal and external customers by meeting their explicit expectation". (De Toro, 1992: hlm 12-13).

Kualitas adalah suatu strategi bisnis yang bersifat mendasar dalam menyediakan barang atau jasa yang benar-benar dapat memuaskan para pemangku kepentingannya dengan cara memenuhi harapan mereka yang bersifat eksplisit (Ali, 2009 : 335).

Untuk lulusan perguruan tinggi, kualitas dapat didefinisikan sebagai kesesuaian antara kemampuan yang dijanjikan perguruan tinggi (jurusan) dengan apa yang diperoleh pemakai lulusan tersebut atau dapat pula didefinisikan sebagai kesesuaian antara harapan pemakai lulusan dengan kemampuan lulusan dalam bekerja. (Nudu, 2000 : 275) 
Jadi, kualitas lulusan adalah kesesuaian antara kemampuan yang dimiliki oleh lulusan dengan harapan dan kebutuhan pihak yang berkepentingan sehingga nantinya tidak akan mengecewakan salah satu pihak yang berkaitan dikarenakan harapan yang diinginkan tidak sesuai dengan realita yang ada. Oleh karena itu, lembaga pendidikan harus selalu mempertimbangkan harapan dan kebutuhan pemangku kepentingan yaitu dengan mempersiapkan lulusan yang berkualitas.

\subsection{DIMENSI KUALITAS LULUSAN}

Kualitas lulusan pendidikan tinggi ditunjukkan dengan tingginya nilai Indeks Prestasi Kumulatif (IPK) dan penyelesaian masa studi yang singkat. (Hasanah, 2006)

Curkovic menjelaskan bahwa Garvin (1984) mengidentifikasi aspekaspek kualitas produk kedalam delapan kategori (dimensi) dimana masingmasing dimensi dapat dijabarkan sesuai produk yang ditinjau (1999, hlm 30). Delapan dimensi kualitas tersebut adalah:performance, features, reliability, conformance, durability, serviceability, aesthetics, danperceived quality.

\section{METODOLOGI PENELITIAN}

\subsection{JENIS PENELITIAN}

Metode penelitian yang digunakan dalam penelitian ini adalah metode penelitian kuantitatif dengan pendekatan data kualitatif. Penelitian kuantitatif dalam penelitian ini dilakukan dengan melakukan penyebaran kuesioner elektronik (google quetioner) kepada mahasiswa alumni STEI SEBI Program Studi Akuntansi Syariah Angkatan 2004-2007. Kuesioner yang dibuat mengacu pada penelitian sebelumnya dan beberapa buku referensi yang berkaitan dengan penelitian. Pendekatan data kualitatif yang dilakukan yaitu dengan menganalisis data yang merupakan hasil kuesioner.

\subsection{VARIABEL DAN PENGUKURAN VARIABEL}

\subsubsection{Kualitas Lulusan}

Kualitas dalam penelitian ini merupakan kualitas dari mahasiswa lulusan Prodi Akuntansi Syariah. Kualitas lulusan diukur dengan teori yang dikemukakan oleh Leo Khadafi (2003: 5) dalam penelitian Melani Oktavia (2005: 2) yaitu menggunakan indikator kecocokan (conformance) dan prestasi (performance). Nilai dari variabel kualitas ditentukan dengan teori perbandingan berpasangan sehingga membentuk matriks dikarenakan skor sub indikator dari performance yaitu IPK dan Masa Studi tidak dapat digabung.

Tabel 1. Perbandingan Berpasangan Penentuan Nilai Variabel Kualitas

\begin{tabular}{|c|c|c|c|}
\hline $\begin{array}{c}\text { Perbandinga } \\
\mathrm{n}\end{array}$ & TINGGI & SEDANG & RENDAH \\
\hline
\end{tabular}




\begin{tabular}{|c|c|c|c|c|c|c|}
\hline $\begin{array}{c}\text { Berpasanga } \\
\text { n }\end{array}$ & $\begin{array}{c}\text { Masa } \\
\text { Studi }\end{array}$ & IPK & $\begin{array}{c}\text { Masa } \\
\text { Studi }\end{array}$ & IPK & $\begin{array}{c}\text { Masa } \\
\text { Studi }\end{array}$ & IPK \\
\hline TINGGI & $8 \mathrm{smt}$ & $\begin{array}{c}3,50- \\
4,00\end{array}$ & $9 \mathrm{smt}$ & $\begin{array}{c}3,50- \\
4,00\end{array}$ & $10 \mathrm{smt}$ & $\begin{array}{c}3,50- \\
4,00\end{array}$ \\
\hline SEDANG & $8 \mathrm{smt}$ & $3,00-3,49$ & $9 \mathrm{smt}$ & $3,00-3,49$ & $10 \mathrm{smt}$ & $3,00-3,49$ \\
\hline RENDAH & $8 \mathrm{smt}$ & $2,50-2,99$ & $9 \mathrm{smt}$ & $2,50-2,99$ & $10 \mathrm{smt}$ & $2,50-2,99$ \\
\hline
\end{tabular}

Apabila lulusan menghabiskan masa studi selama 8 semester, dengan IPK antara 3,50-4,00 maka lulusan berada pada perbandingan TINGGITINGGI, jika masa studi 8 semester dengan IPK antara 3,00-3,49 maka berada pada TINGGI SEDANG, begitupun pasangan lainnya hingga mendapat pasangan yang paling rendah yaitu RENDAH-RENDAH, jika masa studi 10 semester, tetapi IPK hanya antara 2,5-2,99. Kemudian jika terdapat hasil pasangan yang sama maka pasangan tersebut mendapat nilai yang sama (TINGGI-SEDANG = SEDANG-TINGGI).

Gambar 1. Model Hasil Perbandingan Berpasangan
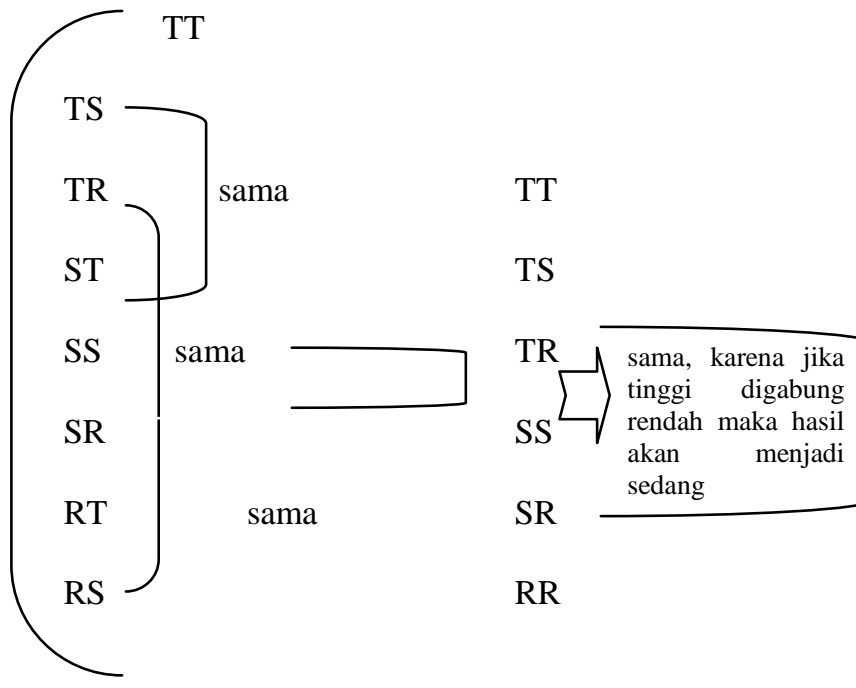

SR

$\mathrm{SR}=1,75$

RR

$\mathrm{RR}=1$

\subsubsection{Motivasi}

Variabel motivasi dalam penelitian ini diukur dengan menggunakan skala likert 4 point. Indikator yang digunakan menggunakan teori Kerlinger dan Pedhazur dalam penelitian (Zurnali, 2011: 6) yaitu Motif (Motive) dan Ekspektasi (Expectantion) (1987, hlm 17).

\subsubsection{Pengetahuan Akuntansi}


Pengetahuan akuntansi dalam penelitian ini adalah pengetahuan akuntansi lulusan Prodi Akuntansi Syariah angkatan 2004-2007. Pengukuran variabel ini didasarkan pada jumlah nilai mata kuliah rumpun akuntansi yang berjumlah 20 mata kuliah dengan penilaian dalam bentuk huruf yang dikuantitatifkan ke dalam bentuk angka, yaitu nilai $\mathrm{A}=4, \mathrm{~B}=3, \mathrm{C}=2$, dan $\mathrm{D}=1$.

\subsubsection{Religiusitas}

Variabel religiusitas dalam penelitian ini menggunakan skala likert 4 point, dengan 5 dimensi yang telah dikemukakan oleh Glock dan Stark, yaitu Religious Believe, Religious Practice, Religious Feeling, Religious Effect, dan Religious Knowledge (1974). Khusus untuk Religious Knowledge, pengukuran menggunakan nilai mata kuliah rumpun Syariah.

\section{PEMBAHASAN}

\subsection{TINGKAT KUALITAS, MOTIVASI, PENGETAHUAN AKUNTANSI, DAN RELIGIUSITAS}

Untuk mengetahui bagaimana tingkat pada variabel penelitian, yaitu tingkat kualitas, motivasi, pengetahuan akuntansi, dan religiusitas lulusan Prodi Akuntansi Syariah digunakan kategori berdasarkan skor yang didapat sesuai data penelitian.

Tabel 2. Deskripsi Data Penelitian Kualitas, Motivasi, Pengetahuan

Akuntansi dan Religiusitas Lulusan Program Studi Akuntansi Syariah

\begin{tabular}{|c|c|c|c|c|c|c|c|c|}
\hline \multirow{2}{*}{ Variabel } & \multicolumn{4}{|c|}{ Hipotetik } & \multicolumn{4}{c|}{ Empirik } \\
\cline { 2 - 10 } & Xmax & Xmin & Mean & SD & Xmax & Xmin & Mean & SD \\
\hline Kualitas & 4 & 1 & 2,5 & 0,5 & 4 & 1,75 & 3,14 & 0,59 \\
\hline Motivasi & 20 & 5 & 12,5 & 2,5 & 20 & 11 & 17,37 & 2,55 \\
\hline Pengetahuan Akuntansi & 80 & 20 & 50 & 10 & 80 & 58 & 67,30 & 5,70 \\
\hline Religiusitas & 100 & 25 & 62,5 & 12,5 & 92 & 73 & 83,64 & 4,94 \\
\hline
\end{tabular}

Berdasarkan data hasil penelitian, skor variabel Kualitas, Motivasi, Pengetahuan Akuntansi, dan Religiusitas Lulusan Prodi Akuntansi Syariah akan diklasifikasikan untuk mengetahui tinggi rendahnya posisi skor subjek. Penentuan kategorisasi didasarkan pada tingkat diferensiasi yang dikehendaki, namun sebelum itu perlu ditetapkan terlebih dahulu batasan yang akan digunakan berdasarkan standar skor hipotetik.

a. Tingkat Kualitas Lulusan Prodi Akuntansi Syariah

Berdasarkan data variabel kualitas lulusan dari subjek penelitian diperolehhasil kategorisasi sebagai berikut : 
Grafik 2. Kategorisasi Tingkat Kualitas Lulusan Prodi Akuntansi Syariah

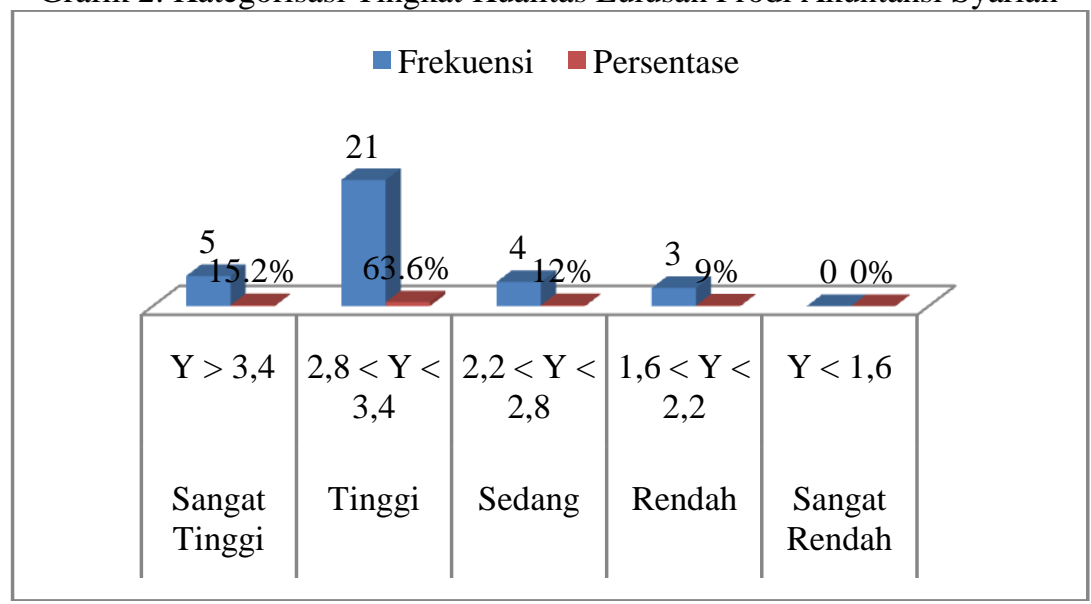

Sumber : data diolah, 2012

Grafik diatas menunjukkan bahwa kualitas lulusan Prodi Akuntansi Syariah memiliki variasi yang cukup, dengan kata lain kualitas lulusan antara satu dengan lainnya tidak memiliki kemiripan atau seragam.

b. Tingkat Motivasi Lulusan Prodi Akuntansi Syariah

Berdasarkan data variabel motivasi lulusan Prodi Akuntansi Syariah dari subjek penelitian diperoleh hasil kategorisasi sebagai berikut:

Grafik 3. Kategorisasi Tingkat Motivasi Lulusan Prodi Akuntansi Syariah

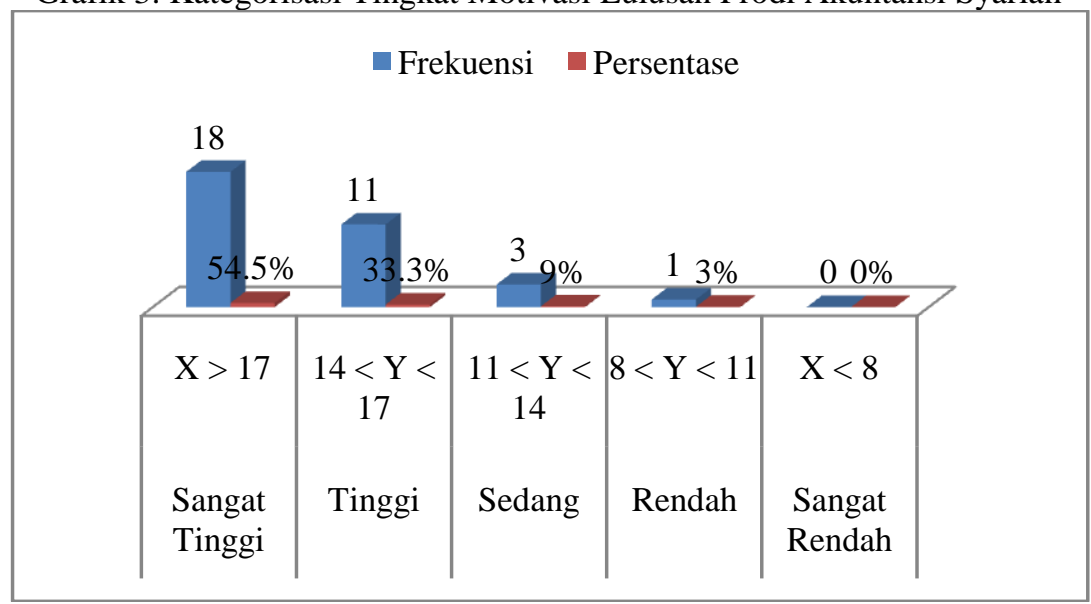

Sumber : data diolah, 2012

Grafik diatas menunjukkan bahwa motivasi lulusan Prodi Akuntansi Syariah memiliki variasi yang cukup, dengan kata lain motivasi lulusan antara satu dengan lainnya tidak memiliki kemiripan atau seragam. 
c. Tingkat Pengetahuan Akuntansi Lulusan Prodi Akuntansi Syariah

Berdasarkan data variabel pengetahuan akuntansi lulusan Prodi Akuntansi Syariah dari subjek penelitian diperoleh hasil kategorisasi sebagai berikut :

Grafik 4. Kategorisasi Tingkat Pengetahuan Akuntansi Lulusan Prodi Akuntansi Syariah

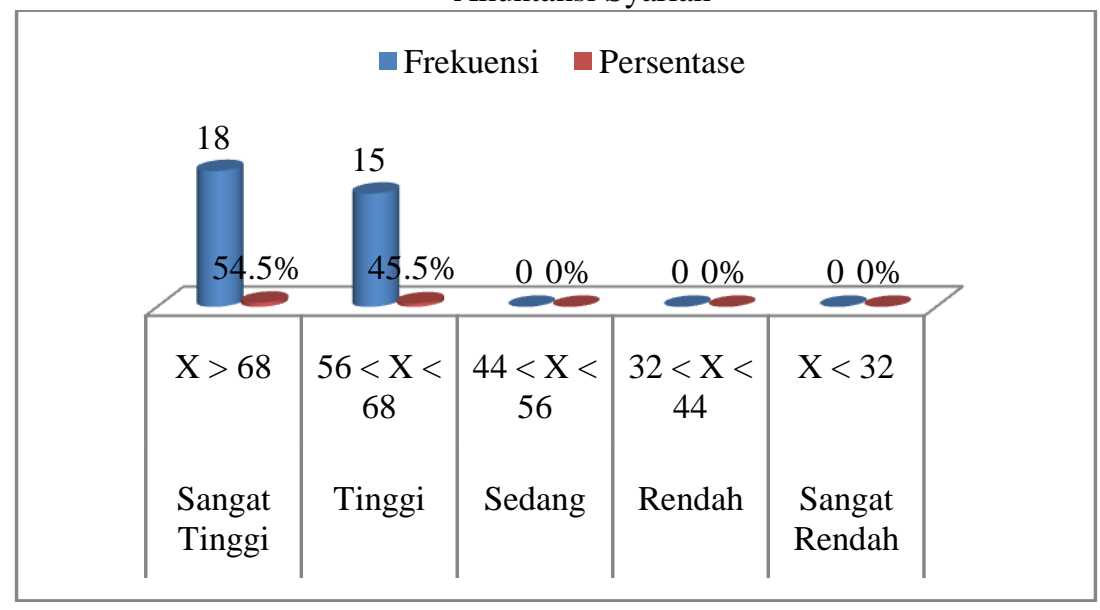

Sumber : data diolah, 2012

Grafik diatas menunjukkan bahwa pengetahuan lulusan Prodi Akuntansi Syariah memiliki variasi yang rendah, dengan kata lain lulusan antara satu dengan lainnya memiliki pengetahuan akuntansi yang seragam.

d. Tingkat Religiusitas

Berdasarkan data variabel religiusitas lulusan Prodi Akuntansi Syariah dari subjek penelitian diperoleh hasil kategorisasi sebagai berikut :

Grafik 5. Kategorisasi Tingkat Religiusitas Lulusan Prodi Akuntansi Syariah

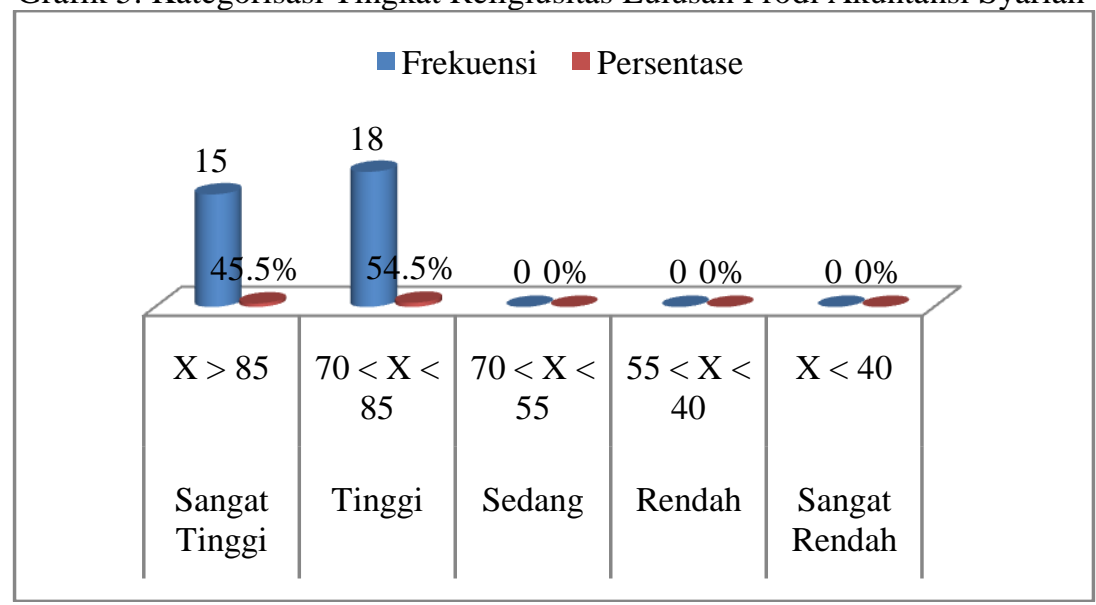

Sumber : data diolah, 2012 
Grafik diatas menunjukkan bahwa pengetahuan lulusan Prodi Akuntansi Syariah memiliki variasi yang rendah, dengan kata lain lulusan antara satu dengan lainnya berada pada religiusitas yang seragam.

\subsection{UJI HIPOTESIS}

Hipotesis penelitian diuji dengan menggunakan analisis regresi berganda. Berdasarkan hasil pengolahan data dengan aplikasi SPSS, maka didapat hasil sebagai berikut

Tabel 3. Uji Koefisien Determinasi

Model Summary ${ }^{\mathrm{b}}$

\begin{tabular}{|l|c|c|c|c|}
\hline Model & $\mathrm{R}$ & R Square & $\begin{array}{c}\text { Adjusted R } \\
\text { Square }\end{array}$ & $\begin{array}{c}\text { Std. Error of the } \\
\text { Estimate }\end{array}$ \\
\hline 1 & $.611^{\mathrm{a}}$ & .373 & .308 & .49607 \\
\hline
\end{tabular}

a. Predictors: (Constant), Religiusitas, Motivasi,

Pengetahuan_Akuntansi

b. Dependent Variable: Kualitas_Lulusan_Performance

Sumber : data diolah, 2012

Pada model summary diatas, dapat dilihat hasil analisa regresi secara keseluruhan nilai $\mathrm{R}$ sebesar 0,611 menunjukkan bahwa antara Kualitas Lulusan dengan Motivasi, Pengetahuan Akuntansi dan Religiusitas mempunyai hubungan yang erat yaitu sebesar $61,1 \%$ karena lebih besar dari $0,5(61,1 \%>50 \%)$.Nilai $R$ Square atau koefisien determinasi adalah sebesar 0,373 . Angka ini mengindikasikan bahwa Motivasi, Pengetahuan Akuntansi dan Religiusitas mampu menjelaskan Kualitas Lulusan sebesar 37,3\% sedangkan selebihnya sebesar $62,7 \%$ dijelaskan oleh faktor-faktor lain yang tidak dijelaskan dalam penelitian ini. Nilai Standar Error of Estimate (SEE) sebesar 0,49607 lebih kecil dari nilai standart deviasi Kualitas Lulusan yaitu sebesar 0,59651, maka model regresi layak digunakan.

Selanjutnya pengujian hipotesis secara statistik dilakukan dengan menggunakan:

\subsubsection{Uji t (Parsial)}

Uji parsial dapat dilihat dari nilai level of significance. Adapun tujuannya yaitu untuk mengetahui hubungan antara variabel-variabel bebas terhadap variabel terikat secara parsial.

Tabel 4. Uji Statistik t (Parsial)

\begin{tabular}{|c|c|c|c|c|c|}
\hline \multicolumn{6}{|c|}{ Coefficients $^{\mathrm{a}}$} \\
\hline \multirow[b]{2}{*}{ Model } & \multicolumn{2}{|c|}{$\begin{array}{c}\text { Unstandardized } \\
\text { Coefficients }\end{array}$} & \multirow{2}{*}{$\begin{array}{c}\begin{array}{c}\text { Standardized } \\
\text { Coefficients }\end{array} \\
\text { Beta }\end{array}$} & \multirow{2}{*}{$\mathrm{t}$} & \multirow{2}{*}{ Sig. } \\
\hline & B & $\begin{array}{l}\text { Std. } \\
\text { Error }\end{array}$ & & & \\
\hline $1 \quad$ (Constant) & -4.304 & 2.049 & & -2.100 & .045 \\
\hline
\end{tabular}




\begin{tabular}{|l|l|c|c|c|c|c|}
\hline & Motivasi & .027 & .189 & .023 & .143 & .887 \\
\cline { 2 - 7 } & Pengetahuan_Akuntansi & .722 & .338 & .346 & 2.138 & .041 \\
\cline { 2 - 7 } & Religiusitas & 1.470 & .445 & .487 & 3.302 & .003 \\
\hline
\end{tabular}
bahwa :

Hasil pengujian statistik secara parsial pada tabel 4.3 menjelaskan

1. Pengaruh Motivasi terhadap Kualitas Lulusan

Dilihat dari level of significance maka nilai signifikan variabel Motivasi sebesar $(0,887>0,05)$, berarti $\mathrm{H}_{\mathrm{a} 1}$ ditolak, bahwa peningkatan dalam Motivasi tidak berpengaruh secara signifikan terhadap Kualitas Lulusan pada tingkat kepercayaan $95 \%$.

Hasil penelitian terdahulu yang dilakukan oleh Byrne \& Flood (2005) dan Arquero, dkk (2009) menyatakan bahwa Motivasi, yang dijabarkan dengan Motif, Harapan, dan Kesiapan mempunyai pengaruh yang positif terhadap Keberhasilan Studi (Performance) seperti halnya dalam penelitian ini. Namun, dalam hal ini motivasi tidak berpengaruh secara signifikan dikarenakan motivasi seseorang dapat berubah setiap waktu. Motivasi awal lulusan berada pada kategori sangat tinggi, tetapi dikarenakan beberapa faktor, seperti perilaku belajar salah satunya. Apabila motivasi belajar lulusan sangat tinggi tetapi tidak di selaraskan dengan perilaku belajar yang baik maka hasil yang akan diperoleh juga menjadi tidak maksimal sehingga kualitas lulusan pun menjadi dipertanyakan.

Motivasi lulusan Prodi Akuntansi Syariah yang terbagi menjadi Motif (Motive) dan Ekspektasi (Expectantion) adalah :

a. Motif lulusan ketika memilih Prodi Akuntansi Syariah adalah memilih Prodi tersebut dapat berkesempatan memperluas wawasan dan menghadapi tantangan baru pada Prodi Akuntansi Syariah. Selain itu juga dikarenakan adanya ketertarikan dengan prospek karir yang tersedia untuk lulusan Akuntansi Syariah.

b. Ekspektasi lulusan dalam memilih Prodi Akuntansi Syariah adalah adanya keinginan untuk dapat mengembangkan pikiran dan kemampuan intelektual dan spiritual, juga agar dapat bekerja di dunia bisnis dan melihat bahwa Prodi Akuntansi Syariah merupakan batu loncatan yang baik sehingga nantinya lulusan akan mendapatkan pekerjaan yang baik.

2. Pengaruh Pengetahuan Akuntansi terhadap Kualitas Lulusan

Dilihat dari level of significance maka nilai signifikan variabel Pengetahuan Akuntansi sebesar $(0,041<0,05)$ berarti $\mathrm{H}_{\mathrm{a} 2}$ diterima bahwa peningkatan dalam pengetahuan akuntansi berpengaruh secara signifikan terhadap Kualitas Lulusan pada tingkat kepercayaan $95 \%$

Hasil dari penelitian ini sama dengan hasil penelitian Siregar (2009) dan Marfuah (2006) bahwa bahwa Pengetahuan Akuntansi mempunyai 
pengaruh positif dan signifikan terhadap Kinerja (performance). Begitu juga dalam penelitian ini bahwa Pengetahuan Akuntansi mempunyai pengaruh positif dan signifikan terhadap Kualitas Lulusan, yang dilihat dari aspek performance karena peningkatan pengetahuan akuntansi dapat meningkatkan kualitas dalam aspek performance, serta Kualitas Lulusan yang dilihat dari performance dapat diukur dengan pengetahuan akuntansi lulusan Prodi Akuntansi Syariah dan pengaruh tersebut signifikan secara statistik.

Hasil penelitian menunjukkan bahwa lulusan Prodi Akuntansi Syariah memiliki skor yang rendah pada mata kuliah Akuntansi Keuangan 2, Akuntansi Keuangan Lanjutan, Akuntansi Biaya, Auditing 1, SIA 1, dan Perpajakan. Skor yang paling rendah berada pada mata kuliah SIA 1 dan Perpajakan berarti bahwa lulusan mengalami kesulitan dalam kedua mata kuliah tersebut. Hal ini dikarenakan tingkat kesulitan mata kuliah yang tinggi dan juga dikarenakan faktor SDM yang mengajar.

3. Pengaruh Religiusitas terhadap Kualitas Lulusan

Dilihat dari level of significance maka nilai signifikan variabel Religiusitas sebesar $(0,003<0,05)$ berarti $\mathrm{H}_{\mathrm{a} 3}$ diterima, bahwa peningkatan dalam Religiusitas berpengaruh secara signifikan terhadap Kualitas Lulusan pada tingkat kepercayaan $95 \%$.

Untuk variabel religiusitas, Fauzan \& Setiawati (2005) menyatakan bahwa religiusitas berpengaruh terhadap kinerja (performance) secara signifikan. Penelitian ini juga menggambarkan bahwa religiusitas berpengaruh signifikan terhadap kualitas lulusan dikarenakan ketika berada di bangku kuliah lulusan telah mengikuti program pembinaan, dimana dalam program tersebut lulusan mendapatkan banyak ilmu-ilmu pengetahuan tentang religiusitas maupun pengetahuan modern lainnya, sehingga segala sesuatu yang didapatkan lulusan tentunya akan mempengaruhi kualitas lulusan.

Dalam penelitian ini, dimensi Religious Knowledge yang diukur dengan nilai mata kuliah rumpun syariah menjelaskan bahwa lulusan Prodi Akuntansi Syariah memiliki skor yang rendah pada mata kuliah Fiqh Muamalah 2 dan memiliki skor yang tinggi pada mata kuliah Tafsir dan Hadits Ahkam.

\subsubsection{Uji F (Simultan)}

Uji F merupakan pengujian yang dilakukan untuk melihat besar pengaruh variabel bebas secara bersama-sama terhadap variabel terikat. Uji $F$ dilakukan dengan menggunakan uji ANOVA (Analysis of Variance), yaitu disajikan sebagai berikut :

Tabel 5. Uji Statistik F (Simultan)

\begin{tabular}{|l|l|c|c|c|c|c|}
\hline \multicolumn{2}{|l|}{ ANOVA $^{\mathrm{b}}$} \\
\hline \multicolumn{2}{|l|}{ Model } & $\begin{array}{c}\text { Sum of } \\
\text { Squares }\end{array}$ & df & $\begin{array}{c}\text { Mean } \\
\text { Square }\end{array}$ & F & Sig. \\
\hline 1 & Regression & 4.250 & 3 & 1.417 & 5.757 & $.003^{\mathrm{a}}$ \\
\hline
\end{tabular}




\begin{tabular}{|l|l|c|c|c|c|c|}
\hline \multirow{2}{*}{} & Residual & 7.136 & 29 & .246 & & \\
\cline { 2 - 7 } & Total & 11.386 & 32 & & & \\
\hline
\end{tabular}

a. Predictors: (Constant), Religiusitas, Motivasi, Pengetahuan_Akuntansi

b. Dependent Variable: Kualitas_Lulusan_Performance

Sumber : data diolah, 2012

Melalui uji ANOVA (Analysis of Variance), didapat F hitung sebesar 5,757 dengan tingkat signifikansi 0,003 . Dikarenakan probabilitas $(0,003)$ lebih kecil dari 0,05 maka menunjukkan bahwa $\mathrm{H}_{\mathrm{a} 4}$ diterima bahwa secara bersama-sama (simultan) seluruh variabel bebas yang terdiri dari Motivasi, Pengetahuan Akuntansi dan Religiusitas mempunyai pengaruh yang signifikan pada tingkat kepercayaan $95 \%$.

Tabel 6. Hasil Analisis Regresi

Coefficients $^{\mathrm{a}}$

\begin{tabular}{|ll|c|c|c|}
\hline \multirow{2}{*}{ Model } & \multicolumn{2}{|c|}{$\begin{array}{c}\text { Unstandardized } \\
\text { Coefficients }\end{array}$} & $\begin{array}{c}\text { Standardized } \\
\text { Coefficients }\end{array}$ \\
\cline { 3 - 5 } & & B & $\begin{array}{c}\text { Std. } \\
\text { Error }\end{array}$ & Beta \\
\hline 1 & (Constant) & $-4,304$ & 2,049 & \\
& Motivasi &, 027 &, 189 &, 023 \\
& Pengetahuan_Akuntansi &, 722 &, 338 &, 346 \\
& Religiusitas & 1,470 &, 445 &, 487 \\
\hline
\end{tabular}

a. Dependent Variable : Kualitas_Lulusan_Performance

Berdasarkan tabel koefisien diatas, pada kolom Unstandardized Coefficients bagian B diperoleh model persamaaan, regresi linier berganda sebagai berikut :

$$
Y=-4,304+0,027 X_{1}+0,722 X_{2}+1,470 X_{3}+e
$$

Keterangan :

$\mathrm{Y}=$ Kualitas Lulusan

$\mathrm{X}_{1}=$ Motivasi

$\mathrm{X}_{2}=$ Pengetahuan Akuntansi

$\mathrm{X}_{3}=$ Religiusitas

Dalam kolom Unstandardized Coefficients menjelaskan bahwa :

1. Nilai B Constant pada tabel diatas yaitu sebesar $-4,304$ (mutlak), nilai konstanta ini menunjukkan bahwa jika variabel motivasi, pengetahuan akuntansi dan religiusitas diabaikan, maka kualitas lulusan diukur dari performance akan mengalami penurunan sebesar 4,304 (43,04\%)

2. Pada variabel motivasi diperoleh nilai koefisien regresi sebesar 0,027. Koefisien regresi ini menunjukkan bahwa variabel motivasi tetap berpengaruh positif terhadap kualitas lulusan, walaupun tidak signifikan 
sebagaimana hasil dari pengujian secara parsial sebelumnya. Jadi, semakin tinggi tingkat motivasi maka semakin tinggi pula kualitas lulusan Program Studi Akuntansi Syariah dan sebaliknya. Setiap variabel Motivasi meningkat $100 \%$ maka Kualitas Lulusan diukur dari performance akan meningkat sebesar $2,7 \%$ dengan asumsi variabel lain dianggap tetap atau cateris paribus.

3. Pada variabel pengetahuan akuntansi diperoleh nilai koefisien regresi sebesar 0,722. Koefisien regresi ini menunjukkan bahwa variabel pengetahuan akuntansi berpengaruh positif terhadap kualitas lulusan Prodi Akuntansi Syariah. Jadi, semakin tinggi pengetahuan akuntansi maka semakin tinggi pula kualitas lulusan Prodi Akuntansi Syariah dan sebaliknya. Setiap variabel Pengetahuan Akuntansi meningkat 100\% maka Kualitas Lulusan diukur dari performance akan meningkat sebesar $72,2 \%$ dengan asumsi variabel lain dianggap tetap atau cateris paribus.

4. Pada variabel religiusitas diperoleh nilai koefisien regresi sebesar 1,470. Koefisien regresi ini menunjukkan bahwa variabel religiusitas berpengaruh positif terhadap kualitas lulusan Prodi Akuntansi Syariah. Jadi, semakin tinggi religiusitas maka semakin tinggi pula kualitas lulusan Prodi Akuntansi Syariah dan sebaliknya. Setiap variabel Religiusitas meningkat $100 \%$ maka Kualitas Lulusan diukur dari performance akan meningkat sebesar $147 \%$ dengan asumsi variabel lain dianggap tetap atau cateris paribus.

\section{SIMPULAN}

Berdasarkan hasil analisis terhadap data yang dikumpulkan, maka dapat diambil kesimpulan sebagai berikut :

1. Berdasarkan analisis deskriptif, tingkat Kualitas dan Religiusitas lulusan Prodi Akuntansi Syariah berada pada kategori sangat tinggi serta tingkat Motivasi dan Pengetahuan Akuntansi berada pada kategori tinggi.

2. Motif lulusan ketika memilih Prodi Akuntansi Syariah adalah memilih Prodi tersebut dapat berkesempatan memperluas wawasan dan menghadapi tantangan baru pada Prodi Akuntansi Syariah. Selain itu juga dikarenakan adanya ketertarikan dengan prospek karir yang tersedia untuk lulusan Akuntansi Syariah.

3. Ekspektasi lulusan dalam memilih Prodi Akuntansi Syariah adalah adanya keinginan untuk dapat mengembangkan pikiran dan kemampuan intelektual dan spiritual, juga agar dapat bekerja di dunia bisnis dan melihat bahwa Prodi Akuntansi Syariah merupakan batu loncatan yang baik sehingga nantinya lulusan akan mendapatkan pekerjaan yang baik.

4. Lulusan Prodi Akuntansi Syariah mendapatkan nilai terendah pada mata kuliah Sistem Informasi Akuntansi (SIA) 1, Perpajakan, dan Fiqh Muamalah 2. 
5. Pada pengujian secara parsial, penelitian ini menunjukkan bahwa walaupun lulusan memiliki motivasi yang sangat tinggi, tetapi variabel Motivasi ini tidak memiliki pengaruh yang signifikan terhadap Kualitas Lulusan Prodi Akuntansi Syariah pada tingkat kepercayaan 95\%. Sedangkan, variabel Pengetahuan Akuntansi dan Religiusitas memiliki pengaruh yang signifikan terhadap Kualitas Lulusan Prodi Akuntansi Syariah.

6. Pada pengujian secara simultan, hasil penelitian ini menunjukkan bahwa seluruh variabel Motivasi, Pengetahuan Akuntansi, dan Religiusitas memiliki pengaruh yang signifikan terhadap Kualitas Lulusan Prodi Akuntansi Syariah.

\section{DAFTAR PUSTAKA}

Al-Qur'anul Karim Tajwid. 2006. Bandung: Syaamil Cipta Media

Aldin, MM dan Nayezadeh. 2011. The Relationship Between Background Variables and The Educational Performance (Case Study: Accounting MA Students). Dalam $2^{\text {nd }}$ International Conference on Education and Management Technology IPCSIT Vol. 13. Singapore: IACSIT Press

Al-Ghazali, Imam. 1988. Ihya Ulumuddin Jiwa Agama Jilid 7. Kuala Lumpur: Victory Ajensi

Al-Ghazali, Imam. 1988. Ihya Ulumuddin Jiwa Agama Jilid 8. Kuala Lumpur: Victory Ajensi

Amalia, E. 2010. Peta Potensi SDM Ekonomi Islam pada PTAI dan PTU: Analisis Kurukulum, Model Pembelajaran dan Hubungannya dengan Kompetensi SDM pada Industri Keuangan Syariah di Indonesia. Laporan Penelitian LEMLIT UIN Syarif Hidayatullah Jakarta .

American Psychiatric Association (APA). 2005. Quality Indicators. Washington, DC.

An-Nabhani, Yusuf. 2006Ringkasan Riyadhush Shalihin Imam Nawawi. Bandung: Irsyad Baitussalam

Bank Indonesia. 2011. "Statistik Perbankan Syariah (Islamic Banking Statistics)". Diambil kembali dari www.bi.go.id.

Basyaib, F. n.d. Teori Pembuatan Keputusan. Jakarta: Grasindo

Byrne, M. 2005. A Study of Accounting Student : Motives, Expectation and Preparedness for Higher Education. Dalam Journal of Further and Higher Education Vol. 29, No. 2 May, (pp. 111-124)

Chupungco, A. J. 1992. Liturgical Inculturation : Sacramentals, Religiosity, and Catechesis. Minnesota, USA : Liturgical Press, Collegevill 
Curkovic, S.dan Shawnee. 1999. Quality and Business Performance : An Empirical Study of First-Tier Automotive Suppliers.

Darmawan, I. 2008. Kiat Jitu Taklukkan Psikotes. Yogyakarta: Widyatama

Direktorat Perbankan Syariah Indonesia. 2011. Outlook Perbankan Syariah 2012.

Erwin, D. A. 2005. Neutral or Unsure: Is there a Difference? Poster Presented at The Annual Meeting of The American Psychological Association. Washington, DC.

Garland, R. 1991. The Mid Point on a Rating Scale: Is it Desirable? Marketing Bulletin, 66-70.

Ghozali, Imam. 2005. Aplikasi Analisis Multivariate dengan Program SPSS. Semarang: Badan Penerbit UNDIP

Glock dan Stark. 1974. American Piety: The Nature of Religious Commitment. California: University of California Press

Gobel, M. 2008. Aspek Sosial Tasawuf Hasan Al-Bashry

Harahab, S. S. 2008. Kerangka Teori dan Tujuan Akuntansi Syariah. Jakarta: Pustaka Quantum.

Hidayat, M. 2008. Hubungan antara Religiusitas dengan Kecemasan Menghadapi Masa Depan pada Survivor Gempa Bumi DIY. Yogyakarta: UII

Ikatan Akuntan Indonesia (IAI). 2007. Pernyataan Standar Akuntansi Keuangan (PSAK). Jakarta: DSAK IAI

Kamal, M. 2011. Metode CHAID dan Korespondensi untuk Menentukan Faktor-Faktor yang Berasosiasi dengan Keberhasilan Studi Mahasiswa. Bogor: Institut Pertanian Bogor (IPB)

Kebutuhan SDM Syariah pada Perbankan Syariah. Diambil kembali dari www.ib.eramuslim.com

Kuncoro, M. 2003. Metode Riset untuk Bisnis dan Ekonomi: Bagaimana meneliti \& menulis tesis? Jakarta: Erlangga.

L, Arquero. 2009. Motives, Expectation, Preparedness, and Academik Performance : A Study of Students of Accounting. Dalam Revista de Contabilidad-Spanish Accounting Review Vol. 12- No. 2. Spanish University.

Malik, M. 2010. Hubungan antara Konsep Diri dengan Prestasi Belajar Siswa MA MuhammadiyahMalang (UMM)

Mircheartaigh, Krosnick dan Armin Helic. 2000. Middle Alternatives, Acquiescence, and The Quality of Questionnaire Data. 
Munandar, A. S. 2001. Psikologi Industri dan Organisasi. Jakarta: UI Press.

Ningsih, R. 2004. Faktor-faktor yang Berpengaruh terhadap Mutu Lulusan SMAN di DKI Jakarta. Tesis, IPB .

Niswonger, Warren, Reeve, dan Fess. 2000. Prinsip-Prinsip Akuntansi. Jakarta: Erlangga.

Nurhayati, S., dan Wasilah. 2009. Akuntansi Syariah di Indonesia. Jakarta: Salemba Empat

Oktavia, M. 2005. Analisis Faktor-Faktor yang Memotivasi Pemilihan Karir bagi Mahasiswa Akuntansi, Bandung: Universitas Widyatama

Profil STEI SEBI. Diambil kembali www.sebi.ac.id.

Reeve, J. M. 2007. Pengantar Akuntansi Adaptasi Indonesia (Principles of Accounting-Indonesia Adaptation). Jakarta: Salemba Empat.

Reitsma, J. 2006, April. Dimension of Individual Religiosity and Charity: Cross-National Effect Differences in European Countries? Review of Religious Research, Vol 47 , hal. 347-362.

Riduwan. 2002. Skala Pengukuran Variabel-Variabel Penelitian. Bandung: Alfabeta.

Santoso, S. 2012. SPSS versi 20. Jakarta: Elex Media Komputindo

Sekaran, U. 2006. Research Methods For Business-Metodologi Penelitian. Jakarta: Salemba Empat.

Siregar A.F 2009. Pengaruh Pengetahuan Akuntansi dan Kepribadian Wirausaha terhadap Kinerja Manajerial pada Perusahaan Jasa, Medan : Universitas Sumatera Utara (USU)

Singgih, M.dan Rahmayanti. 2008. Faktor-faktor yang Mempengaruhi Kualitas Pendidikan pada Perguruan Tinggi, Yogyakarta: November, ITS

Soemarso. 1999. Akuntansi Suatu Pengantar. Jakarta: Rineka Cipta.

Subowo dan Marfuah. 2006. Hubungan antara Pengetahuan Akuntansi, Pengalaman Kerja, dan Etika Kerja Islam dengan Kinerja Pegawai Unit Pertanggungjawaban Keuangan di Lingkungan Badan Wakaf UII. Dalam Fenomena Vol. 4 No.2, September

Suwardjono. 2002. Akuntansi Pengantar. Yogyakarta: BPFE-Yogyakarta

Syahatah, H. 2001. Pokok-Pokok Pikiran Akuntansi Islam. Jakarta: Akbar Media Eka Sarana.

Sugiyono. 2008. Metode Penelitian Bisnis. Bandung: Alfabeta.

Suharyadi. 2009. Statistika Untuk Ekonomi dan Keuangan Modern Edisi 2. Jakarta: Salemba Empat 
Sutrisno, E. 2009. Manajemen SDM. Jakarta: Kencana Prenada Media Group. Thomset, Rob. 2003. Radical Project Management

Thontowi. n.d. Diklat Keagamaan Palembang, Widya Iswara Madya

Triyuwono, I. 2006. Perspektif, Metodologi, dan Teori. Jakarta: Rajawali Press.

Trihendradi, Cornelius. 2005. Step by Step SPSS 13 Analisis Data Statistik. Yogyakarta: Penerbit ANDI

Widhiarso, W. 2010. Pengembangan Skala Psykologi : Lima Kategori Respons ataukah Empat Kategori Respons? Yogyakarta: UGM.

Widrick, S. M. 2002. Measuring The Dimensions of Quality in Higher Education. Routledge, Total Quality Manajemen, Vol. 13 No. 1 , pp 123-131

Yusup, H. (2005). Dasar-Dasar Akuntansi. Yogyakarta: Sekolah Tinggi Ilmu Ekonomi (STIE) YKPN

Zurnali, C. 2011. Pengaruh Pelatihan dan Motivasi terhadap Perilaku Produktif Karyawan di Divisi Long Distance PT. Telkom Tbk. Indonesia. Dalam Jurnal Kajian Oikos-Nomos Vol. 4 No. 1, Januari 